
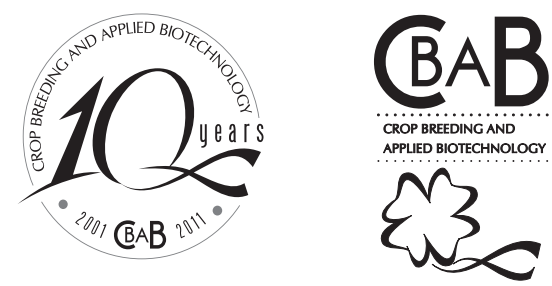

\title{
Genetic diversity in natural populations of Buriti (Mauritia flexuosa L. f.)
}

Liene Rocha Picanço Gomes ${ }^{1}$, Maria Teresa Gomes Lopes ${ }^{1}$, Jania Lilia da Silva Bentes ${ }^{1}$, Willian Silva Barros ${ }^{2}$, Pedro de Queiroz Costa Neto ${ }^{1}$ and Luis Antônio Serrão Contim ${ }^{3}$

Received 14 October 2010

Accepted 16 January 2011

\begin{abstract}
This study aimed to characterize the genetic diversity of buriti populations by AFLP (Amplified Fragment Length Polymorphism) markers. The analysis was performed in four populations used by traditional communities in the state of Amazonia (Bom Jesus do Anamã, Lauro Sodré, Santa Luzia do Buiçuzinho, and Esperança II). From each population 30 plants were randomly selected. To obtain the markers four primer combinations were used. The percentage of polymorphic loci was estimated, the molecular variance among and within populations analyzed and a dendrogram constructed. The primers detected 339 polymorphic loci ranging from $81.1 \%$ to $91.1 \%$ among populations. Analysis of molecular variance attributed $77.18 \%$ to variation within and $22.8 \%$ to variation between populations. The dendrogram indicated the formation of two groups, showing that the populations of Bom Jesus do Anamã and Lauro Sodré are genetically most similar and thet the genetic and geographical distances are not correlated.
\end{abstract}

Key words: Genetic variability; molecular markers; palm.

\section{INTRODUCTION}

Buriti (Mauritia flexuosa L. f.) is a palm tree of the family Arecaceae restricted to South America, widespread across the Amazon region (Henderson 1995). It is a still undomesticated, highly promising species that thrives even in nutrient-poor, acidic and flooded soils unsuitable for agriculture.

This palm is important in view of its ornamental value, but also has strategic importance in wildlife preservation, since its fruit is a food source for many birds and mammals. It is also widely used in cooking in the Amazon, in sweets and jams, for oil extraction and is rich in vitamin A (Henderson 1995). The fruits are also popular for medicinal uses, perfect for handicrafts and bio-jewelry, and is a natural indicator of areas with water resources.

In the surroundings of isolated communities in the Amazon, e.g., Bom Jesus do Anamã, Lauro Sodré, Santa Luzia do Buiçuzinho e Esperança II, natural buriti populations can be found..? If used adequately, the use of natural populations of this species may turn out to be an alternative response to the need for an improved life quality of local populations and for community development. In this sense, local resources should be valued, studied, to convert them into benefits for the development of the numerous isolated Amazonian communities with difficult access.

\footnotetext{
${ }^{1}$ Universidade Federal do Amazonas (UFAM), Avenida General Rodrigo Otávio Jordão Ramos, 3000, Aleixo, 60.077-000, Manaus, AM, Brazil. *E-mail: mtglopes@ufam.edu.br

${ }^{2}$ Universidade Federal de Pelotas, Campus Capão do Leão, s/n, 96.001-970, Capão do Leão, RS, Brazil

${ }^{3}$ Universidade Federal de Goiás, Campus Jataí, BR 364, km 192, 75.801-615, Jataí, Goiás, Brazil
} 
Knowledge on the genetic diversity within and among natural populations allows a better understanding of how selection works on the basis of adaptability, because the higher the genetic variability in a population, the greater the chance of perpetuation of the species (Estopa et al. 2006). Studies on genetic diversity have also been conducted to support the preservation and improvement of a species (Esfahani et al. 2009, Setotaw et al. 2010).

Molecular markers have been used extensively and successfully in the genetic analysis of plants and to characterize the variability among plants. In the study of genetic diversity, the AFLP (Amplified Fragment Length Polymorphism) technique is particularly interesting, for detecting a greater number of loci than others that identify molecular markers; this method provides extensive genome coverage at a low cost per data unit (locus) (Ferreira and Grattapaglia 1998, Lopes et al. 2002).

Studies on the genetic diversity of $M$. flexuosa are scarce and the knowledge and organization of genetic variability is an important step towards genetic conservation and for future breeding work. The purpose of this study was to characterize the genetic diversity of natural buriti populations by AFLP markers.

\section{MATERIAL AND METHODS}

Samples were collected from four natural buriti populations located at points along the gas pipeline CoariManaus: Bom Jesus do Anamã (61 ${ }^{\circ} 17^{\prime} 49^{\prime \prime}$ W and $3^{\circ} 36^{\prime}$ 36 ” S), Lauro Sodré (62 $35^{\prime}$ '29" W and $3^{\circ} 51^{\prime}$ '28” S), Santa Luzia do Buiçuzinho (63 25' 22" W, $4^{\circ} 00^{\prime} 58^{\prime \prime} \mathrm{S}$ ) and Esperança II (630 $00^{\prime} 59^{\prime \prime} \mathrm{W}$ and $\left.3^{\circ} 59^{\prime} 58^{\prime \prime} \mathrm{S}\right)$. Leaves were collected from 30 randomly sampled plants in each population. The trees were georeferenced and the respective geographical coordinates recorded. The material was packed in plastic bags with silica gel for later DNA extraction.

DNA was extracted using the cationic detergent CTAB (2\% cationic hexadecyl trimethyl ammonium bromide) (Doyle and Doyle 1987), with proteinase K, according to the protocol modified by Grattapaglia and Ferreira (1998). The comparative method in $1 \%$ agarose gel was used for quantification, using markers with known molecular weight (50 and $100 \mathrm{ng}$ ). The agarose gel was stained with ethidium bromide (Ferreira and Grattapaglia 1998) and visualized by UV transillumination.

For the DNA digestion reactions, a combination of restriction enzymes EcoRI/MseI was used: $200 \mathrm{ng}$ of genomic DNA, 5.0 $\mu \mathrm{L}$ buffer One Phor All 10X (OPA;
Amersham), $0.5 \mu \mathrm{L}$ BSA (bovine serum albumin) solution $\left(10 \mu \mathrm{g} \mathrm{mL}^{-1}\right), 0.5 \mu \mathrm{L}$ of enzyme MseI (10 units $\mu \mathrm{L}^{-1}$, New England Biolabs) and $0.4 \mathrm{~mL}$ of the enzyme EcoRI (12 units $\mu \mathrm{L}^{-1}$, Gibco), in a final volume of $50 \mu \mathrm{L}$. The reactions were performed at $37^{\circ} \mathrm{C}$ for three hours then the enzymes were inactivated at $70^{\circ} \mathrm{C}$ for 15 minutes.

In the pre-amplification reactions, complementary primers to the sequences of the restriction enzyme sites with one selective nucleotide were used, in this case the primer combination $\mathrm{E}+\mathrm{A} / \mathrm{M}+\mathrm{C}$. The preamplification products were diluted by adding $40 \mathrm{~mL}$ ultrapure water for amplification. In the selective amplification, 13 primer combinations were used in a random sample of 10 plants of the populations: EcoRI-AAC/MseI-CAC, EcoRI-AAC/ MseI-CCA, EcoRI-AAC/MseI-CGC, EcoRI-AAC/MseICTC, EcoRI-ACA/MseI-CCA, EcoRI-ACA/MseI-CGC, EcoRI-ACA/MseI-CTC, EcoRI-ACA/MseI-CAT, EcoRIAGC/MseI-CAC, EcoRI-AGC/MseI-CAT, EcoRI-ATC/ MseI-CCA, EcoRI-ATC/MseI-CTC and EcoRI-AGT/MseI$C G C$. The primers with the highest number of polymorphic loci were amplified in all plants of the populations. For the reactions of Selective PCR (Polymerase Chain Reaction) amplification $2.5 \mu \mathrm{L}$ of the diluted pre-amplification product in a thermocycler (Techine TC-512) was used. Before applying the samples for electrophoresis, a pre-run was carried out at constant power of $50 \mathrm{~W}$ for $1 \mathrm{~h}$, to warm up and cleanse the gels. After sample application, electrophoresis was performed at a constant $50 \mathrm{~W}$ and run-time of approximately 4 hours.

The gel was stained by the silver nitrate method according to the protocol proposed by Creste et al. (2001). The polymorphic loci were analyzed for the presence/ absence of amplified fragments. The AFLP markers were labeled with a code whose first two letters indicate the enzymes used in digestion $(E c o \mathrm{RI}=\mathrm{E}$ and $M s e \mathrm{I}=\mathrm{M})$, the third and fourth characters are numbers that identify the combinations according to the variation in primer extensions. After these four traits that identify the combination of enzymes and primers, the size of the amplified locus fragment in the number of base pairs was added. From the fragments, a 0-1 matrix was constructed, where 1 indicates presence and 0 absence of fragments.

The percentage of polymorphic loci was estimated for each population and all populations together by the program Popgene version 1.32 (Yeh et al. 1999). The distribution of genetic variation among and within populations was quantified by analysis of molecular variance (Amova), using software Genes (Cruz 2006). 
The genetic distances between and within populations were calculated based on the method of Nei (1978). These genetic distances were used to construct the dendrogram by UPGMA (Unweighted Pair Group Method using Arithmetical Averages) cluster analysis. The consistency of the groupings was tested by 5000 bootstrap resamplings, using software Tfpga (Tools for population genetic analysis) version 1.3 (Miller 1997) for the estimates. Additionally, the gene flow was analyzed, using the program Popgene version 1.32 (Yeh et al. 1999).

\section{RESULTSANDDISCUSSION}

Of the 13 primer combinations tested, all produced fragments with satisfactory intensity and a good amplification profile. Of these, four combinations were used in this study (E-AAC/M-CAC, E-AAC/M-CGC, E-ACA/M-CGC, and EATC/M-CCA), due to the larger number of amplified polymorphic loci per primer combination.

The primer combinations used in the four populations produced 339 bands, ranging from 66 to 101 loci per primer combination. The average percentage of polymorphic loci detected in each population per primer combination ranged from $82 \%$ in Bom Jesus do Anamã to $91.1 \%$ in Santa Luzia do Buiçuzinho. The polymorphism level of the populations of Lauro Sodré and Esperança II was intermediate $(82.5 \%$ and $88 \%$, respectively). When the four combinations were analyzed considering the sum of the loci of the four primer combinations, it was found that in Santa Luzia Buiçuzinho the polymorphism percentage was equal to the average polymorphism, while at the other sites these values varied little (Table 1). In studies on the palm species Euterpe edulis, Cardoso et al. (2000) used five primer pairs and found 429 fragments of which 395 (92\%) were polymorphic. To evaluate the existence of three races of peach palm, a domesticated species, Clement et al. (2002) used six primer combinations generating 245 fragments, of which 135 (55.1\%) were polymorphic.

The polymorphism levels of the AFLP markers were high when compared with other dominant markers such as RAPD. Oliveira et al. (2007) characterized the genetic diversity of Euterpe oleracea accessions using 28 RAPD primer pairs and found 263 polymorphic bands. To characterize the genetic variability of Butia capitata of the Active Germplasm Bank (BAG) of the UFPel (Federal University of Pelotas) by RAPD, Nunes et al. (2008) used 21 primer pairs, which produced 136 fragments of which 77 were polymorphic, a very small number when compared with the AFLP marker.
The distribution of genetic variability among and within populations (Table 2) showed that populations account for $24.74 \%$ and plants within populations for $77.18 \%$ of the genetic variability. The $F$ st value was 0.23 (Table 6); it is noteworthy that the values were highly significant $(\mathrm{P}<0.001)$.

These results agree with several other studies on tree species using molecular markers, which reported that the greatest genetic diversity is found within populations. In Euterpe edulis, there was $57.4 \%$ of diversity within populations (Cardoso et al. 2000); in M. urundeuva this value was $83.8 \%$ (Freitas et al. 2005); in Eremanthus erythropappus $79 \%$ (Estopa et al. 2006) and in one açai species of the genus Euterpe, Oliveira and Silva (2008) found a variability of $75.85 \%$ for dominant markers, RAPD and $69.88 \%$ for co-dominant SSR markers.

The allelic flow among populations was low $(\mathrm{Nm}=2.99)$ (Table 3). The greatest gene flow occurred in the populations of Bom Jesus and Lauro Sodré (10.71) and the lowest in the populations of Bom Jesus and Esperanza II (3.01).

The average genetic distance between buriti populations was 0.0564 (Table 3 ). The genetic distance was shortest between the populations of Bom Jesus do Anamã and Lauro Sodré (0.0205) and greatest between the populations of Bom Jesus do Anamã and Esperança II (0.0938). The low value of gene flow may be related to the geographic distance separating the populations.

Based on the mean genetic similarity, calculated for 120 plants of $M$. flexuosa, the dendrogram (Figure 1) shows the formation of two groups; the first comprised the populations of Bom Jesus and Lauro Sodré and the second the populations of Buiçuzinho and Esperança II. This result is supported by a high bootstrap value $(2,000$ resamplings)

The results of this study suggest that although much of the genetic variation of the species is at the intrapopulation level, the genetic differentiation among buriti populations is significant. Management and conservation plans for $M$. flexuosa must observe the genetic variability in these populations in order to ensure the preservation of the genetic resources of the species. To make sure that most of the variability is preserved, the populations in each of these areas must be preserved.

The dendrograms of genetic distances per population showed high variability within populations (Figures 2 and 3 ). The distribution of plants of the population of Bom Jesus do Anamã shows the formation of eight groups and 
Genetic diversity in natural populations of Buriti (Mauritia flexuosa L. f.)

Table 1. Number of loci detected per primer combination and percentage of polymorphic loci for each Mauritia Flexuosa population

\begin{tabular}{lccccc}
\hline \multirow{2}{*}{ Primer Combination } & \multirow{2}{*}{ Number of loci } & \multicolumn{4}{c}{ \% of polymorphic loci } \\
\cline { 3 - 6 } & & Bom Jesus do Anamã & Lauro Sodré & Esperança II & $\mathbf{S}^{\text {ta }}$ Luzia do Buiçuzinho \\
\hline E-ACA/M-CGC & 88 & 50 & 62.5 & 77.3 & 90.1 \\
E-AAC/M-CAC & 101 & 96 & 95 & 84.2 & 87.1 \\
E-AAC/M-CGC & 84 & 82.1 & 76.2 & 96.4 & 96.4 \\
E-ATC/M-MCA & 66 & 100 & 100 & 98.5 & 90.9 \\
\hline Mean & & $\mathbf{8 2}$ & $\mathbf{8 3 . 4}$ & $\mathbf{8 9 . 1}$ & $\mathbf{9 1 . 1}$ \\
\hline Total & $\mathbf{3 3 9}$ & $\mathbf{8 1 . 1}$ & $\mathbf{8 2 . 5}$ & $\mathbf{8 8}$ & $\mathbf{9 1 . 1}$ \\
\hline
\end{tabular}

Table 2. Analysis of molecular variance

\begin{tabular}{lccccc}
\hline Source of variation & df & Sum of squares & Components of variation & \% of variation & $\boldsymbol{P}$ \\
\hline among & 3 & 1368 & 13.6601 & 22.82 & $<0.0001$ \\
within & 116 & 5358.8667 & 46.1971 & 77.18 & $<0.0001$ \\
\hline Total & $\mathbf{1 1 9}$ & $\mathbf{6 7 2 6 . 8 6 6 7}$ & $\mathbf{5 9 . 8 5 7 2}$ & $\mathbf{1 0 0}$ & \\
\hline
\end{tabular}

$F s t=0.23$

Table 3. Estimates of the allele flow (above the diagonal) and genetic distance (below the diagonal) of Nei (1978), among the Mauritia flexuosa populations

\begin{tabular}{lcccc}
\hline Populations & BJ & LS & ESP & BU \\
\hline BJ & $* * * * *$ & 10.70 & 3.01 & 4.34 \\
LS & 0.0205 & $* * * * *$ & 3.45 & $* .68$ \\
ESP & 0.0938 & 0.0786 & 5.92 & 00408 \\
BU & 00553 & 00496 & $* * * *$ \\
\hline
\end{tabular}

BJ, LS, ESP and BU are Bom Jesus do Anamã, Lauro Sodré, Esperança II and Buiçuzinho, respectively.

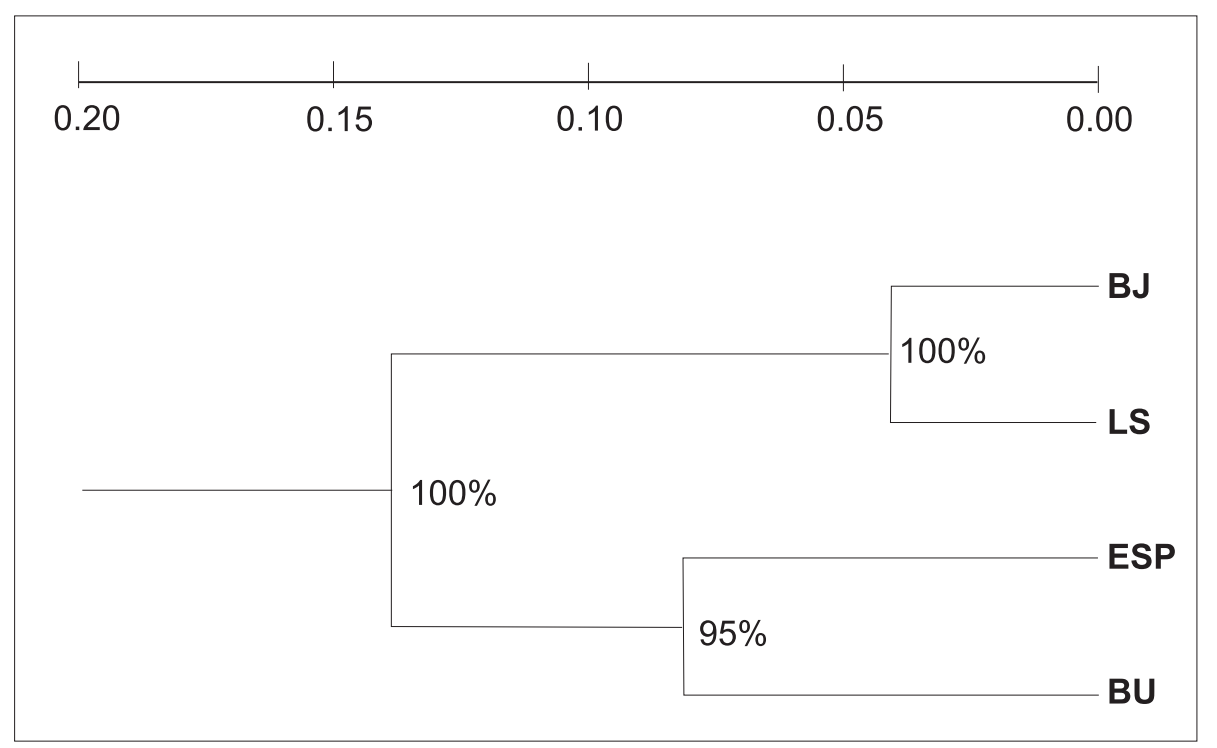

Figure 1. UPGMA dendrogram of Mauritia flexuosa populations, calculated based on the genetic identity of Nei (1978). The numbers in the branches are results of the bootstrap test with 2.000 replications. BJ: Bom Jesus do Anamã; LS: Lauro Sodré; ESP: Esperança II; BU: Buiçuzinho. 
LRP Gomes et al.
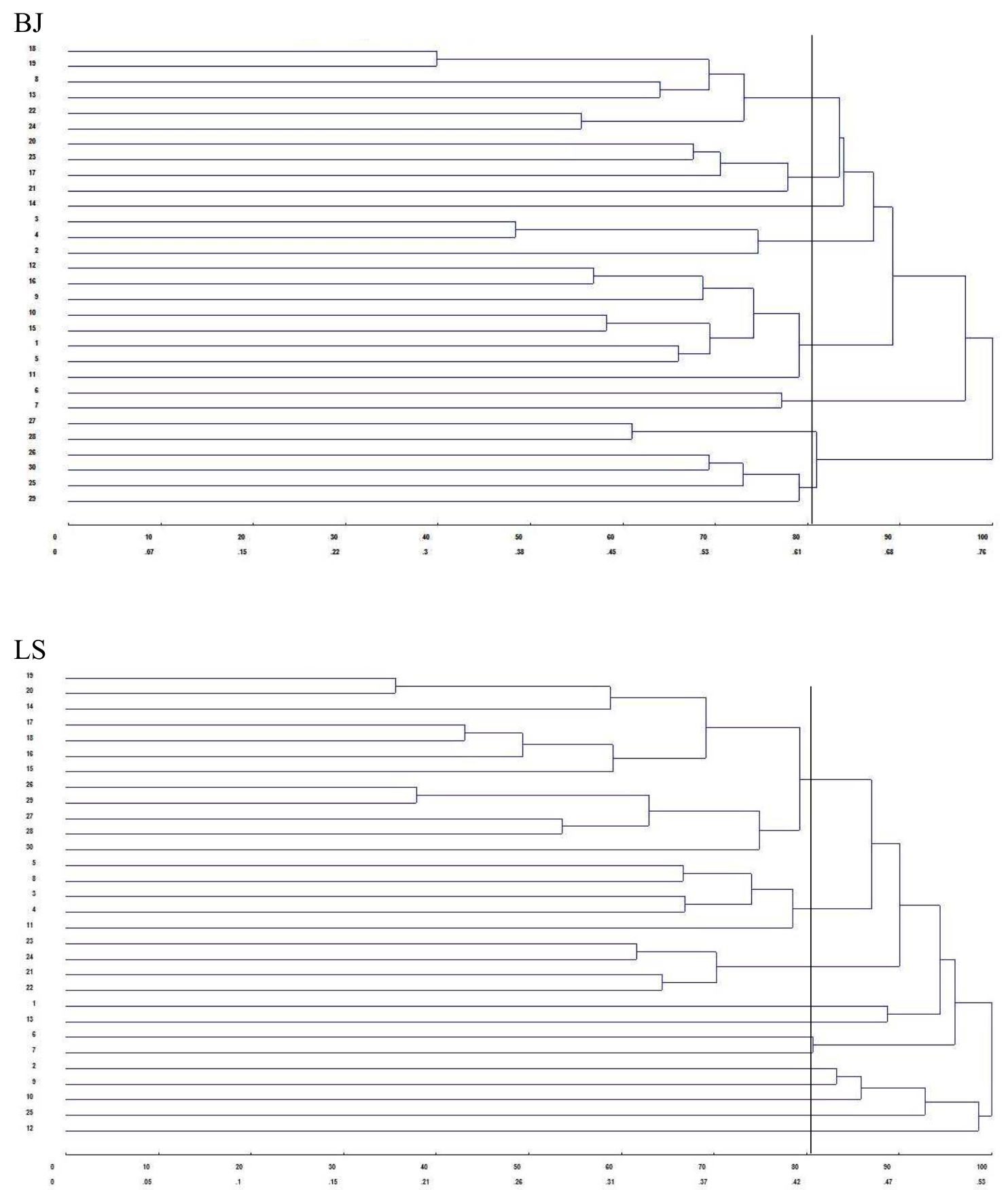

Figure 2. UPGMA dendrogram of Mauritia flexuosa populations, calculated based on the genetic identity of Nei (1978). BJ: Bom Jesus do Anamã; LS: Lauro Sodré. 
Genetic diversity in natural populations of Buriti (Mauritia flexuosa L. f.)
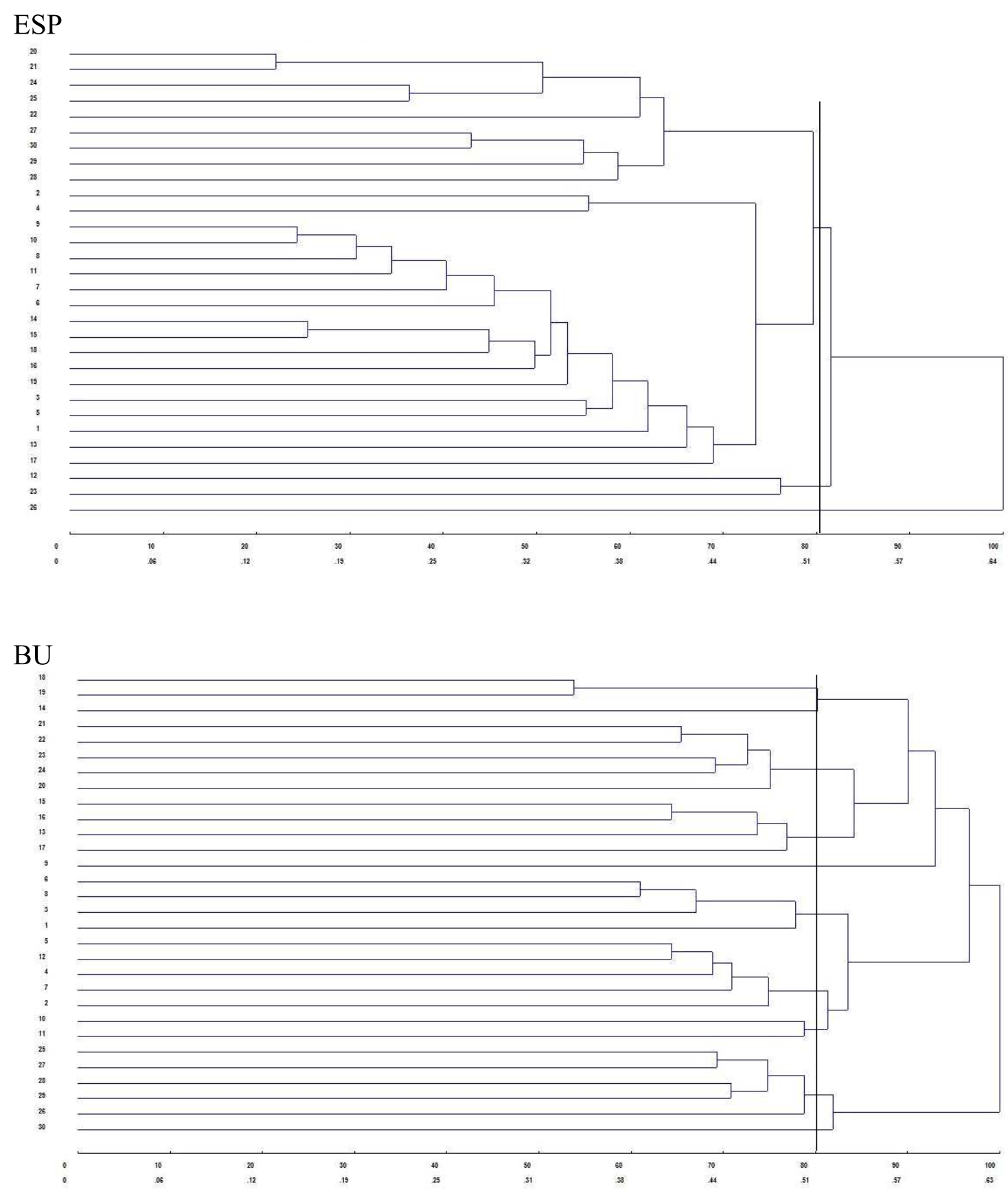

Figure 3. UPGMA dendrogram of Mauritia flexuosa populations, calculated based on the genetic identity of Nei (1978). ESP: Esperança II; BU: Buiçuzinho. 


\title{
LRP Gomes et al.
}

the population of Lauro Sodré of 12 groups (Figure 2). Three groups were formed of the population of Esperança II and 10 of the population of Buiçuzinho (Figure 3).

In view of the pattern of genetic variability observed in buriti and since the species is allogamous (random intercrossing among plants), a representative set of genes contained in the plants of each population must be sampled for species conservation, which can result in a high number of plants in an ex situ collection. Field collections require a constant investment of resources for maintenance. Experiences with field conservation of perennial species native to the Amazon region showed that a participatory in situ conservation of buriti would be desirable in areas where this species is used by people, as in the traditional communities. With the in situ conservation, efforts and resources could be concentrated on small study collections, including only the most promising genotypes, selected in situ, and which may, in the very first cycle of selection, become the first fields of seed production for planting.

\section{ACKNOWLEDGEMENTS}

The authors wish to thank the Financiadora de Estudos e Projetos (FINEP), Fundação de Amparo à Pesquisa do Estado do Amazonas (FAPEAM) and the Conselho Nacional de Pesquisa e Desenvolvimento (CNPq) for funding the research.

\section{Diversidade genética em populações naturais de Buriti (Mauritia flexuosa L. f.)}

\begin{abstract}
RESUMO - O trabalho objetivou caracterizar a diversidade genética de populações de buriti por meio de marcadores AFLP (Amplified Fragment Length Polymorphism). A análise foi realizada em quatro populações utilizadas por comunidades tradicionais do estado do Amazonas (Bom Jesus do Anamã, Lauro Sodré, Santa Luzia do Buiçuzinho e Esperança II). Foram amostrados aleatoriamente 30 indivíduos em cada população. Para a obtenção dos marcadores foram utilizadas quatro combinações de primers. Foi estimada a porcentagem de locos polimórficos, realizada análise de variância molecular entre e dentro de populações e construído dendograma. Os primers revelaram 339 locos polimórficos variando de $81,1 \%$ a 91,1\% entre as populações. A Análise molecular de variância atribuiu $77,18 \%$ de variação dentro e 22,82 \% entre as populações. O dendograma revelou a formação de dois grupos, mostrando que as populações de Bom Jesus do Anamã e Lauro Sodré são as mais semelhantes geneticamente e que as distâncias genéticas não estão correlacionadas com a distância geográfica.
\end{abstract}

Palavras-chave: variabilidade genética; marcador molecular; palmeira.

\section{REFERENCES}

Cardoso SRS, Eloy NB, Provan J, Cardoso MA and Ferreira PCG (2000) Genetic differentiation of Euterpe edulis Mart. populations estimated by AFLP analysis. Molecular Ecology 9: $1753-1760$.

Clement CR, Souza NR, Rodrigues DP, Astolfi-Filho S, Moreno YN, Pascual VT and Rodríguez FJG (2002) Use of AFLPs to distinguish landraces of Pajibaye (Bactris gasipaes) in Brazilian Amazonia. Scientia Agricola 59: 749-753.

Creste S, Tulmann Neto A and Fiqueira A (2001) Detection of single sequence repeat polymorphisms in denaturing polyacrylamide sequencing gels by silver staining. Plant Molecular Biology Reporter 19: 299-306.
Cruz CD (2006) Programa Genes: análise multivariada e simulação. Editora UFV, Viçosa, 175p.

Doyle JJ and Doyle JI (1987) Isolation of plant DNA from fresh tissue. Focus 12: 13-15.

Esfahani ST, Shiran B and Balali G (2009) AFLP markers for the assessment of genetic diversity in European and North American potato varieties cultivated in Iran. Crop Breeding and Applied Biotechnology 9: 75-86.

Estopa RA, Souza AM, Moura MCO, Botrel MCG, Mendonça EG and Carvalho D (2006) Diversidade genética em populações naturais de candeia (Eremanthus erythropappus (DC.) MacLeish). Scientia Forestalis 70: 97-106. 
Ferreira ME and Grattapaglia D (1998) Introdução ao uso de marcadores moleculares em análise genética. $3^{\text {rd }}$ ed., Embrapa/Cenargen, Brasília, 222p.

Freitas MLM, Aukar APA, Sebbenn AM, Moraes MLT and Lemos EGM (2005) Variabilidade genética intrapopulacional em Myracrodruon urundeuva Fr. All. por marcador AFLP. Scientia Forestalis 68: 21-28.

Henderson A (1995) The palms of the Amazon. Oxford University Press, New York, 326p.

Lopes R, Lopes MTG, Figueira AVO, Camargo LEA, Fungaro MHP, Carneiro MS and Vieira MLC (2002) Marcadores moleculares dominantes (RAPD e AFLP): aspectos técnicos e interpretação genética. Biotecnologia Ciência e Desenvolvimento 29: 64-68.

Miller MP (1997) Tools for population genetics analyses 1.3 a Windows program for the analysis of allozyme and molecular population genetic data. Available at <http://www.marksgenetic software.net/tfpga.htm> Acessed on June 2010.
Nei M (1978) Estimation of average heterozygosity and genetic distance from a small number of individuals. Genetics 89: 583-590.

Nunes AM, Bianchi VJ, Fachinello JC, Carvalho AZ and Cardoso G (2008) Caracterização molecular de butiazeiro por marcadores RAPD. Revista Brasileira de Fruticultura 30: 702-707.

Oliveira MSP, Amorim EP, Santos JB and Ferreira DF (2007) Diversidade genética entre acessos de açaizeiro baseada em marcadores RAPD. Ciência e Agrotecnologia 31: 1645-1653.

Oliveira MSP and Silva KJD (2008) Diferenciação genética entre procedências de açaizeiro por marcadores RAPD e SSR. Revista Brasileira de Fruticultura 30: 438-443.

Setotaw TA, Dias LAS and Missio RF (2010) Genetic divergence among barley accessions from Ethiopia. Crop Breeding and Applied Biotechnology 10: 116-123.

Yeh FC, Yang RC and Boyle T (1999) Microsoft Windows based freeware for population genetic analysis. Popgene, version 1.32. Available at <http://www.marksgenetic software.net/ tfpga.htm> Assessed on June 2010. 